\title{
Use of Bio-Resources for Remediation of Soil Pollution
}

\author{
Sharmistha Pal ${ }^{1}$, Ashok K. Patra ${ }^{2 *}$, Sah Kausar Reza ${ }^{3}$, Walter Wildi ${ }^{4}$, John Poté ${ }^{4}$ \\ ${ }^{1}$ Central Soil and Water conservation Research and Training Institute, Research Centre, Madhya Marg, India; ${ }^{2}$ Division of Soil \\ Science and Agricultural Chemistry, Indian Agricultural Research Institute, New Delhi, India; ${ }^{3}$ National Bureau of Soil Survey and \\ Land Use Planning, Jorhat, India; ${ }^{4}$ University of Geneva, Forel Institute, Versoix, Switzerland. \\ Email: patraak@gmail.com
}

Received October $28^{\text {th }}, 2010$; revised December $4^{\text {th }}, 2010$; accepted December $6^{\text {th }}, 2010$.

\begin{abstract}
In recent years, economic boom in fast developing countries has been witnessed with spectacular progress in industrialization and concurrent progress in modern agriculture. Such development is however not without any socio-political and environmental side effects. A major concern has been the environmental pollution. If the current unabated disposal of various forms of wastes to agricultural lands is continued, the inherent capacity of soil to support agricultural production and sustain other ecosystem services will be in peril. Heavy metals with soil residence times of thousands of years present numerous health hazards to higher organisms. They are also known to decrease plant growth, ground cover and have a negative impact on soil biodiversity. Inorganic and organic contaminants typically found in urban areas are heavy metals and petroleum derived products. The presence of both types of contaminants on the same site presents technical and economic challenges for decontamination strategies. In this article we have reviewed the developments to ameliorate the contaminated soils, with special emphasis on biological approaches, which have shown potential to low-cost remediation of soil pollution. Also the limitations of such approaches and direction of further research have been highlighted.
\end{abstract}

Keywords: Soil pollution, Bioremediation, Phytoremediation, Metals, Organic Pollutants, Rhizosphere

\section{Introduction}

Intense industrial activity in the 20th century, especially in developing countries, has led to serious environmental pollution, resulting in a large number and variety of contaminated sites which became a threat to the local ecosystems. In India, the application of industrial and city effluents to land has become popular in recent years as an alternative means of treatment and disposal [1-3]. Heavy metals, with soil residence times of thousands of years, present numerous health dangers to higher organisms [4]. They are also known to decrease plant growth, ground cover and have a negative impact on soil microflora [5]. There is increasing and widespread interest in the maintenance of soil quality and remediation strategies for management of soils contaminated with trace metals, metalloids or organic pollutants. Heavy metals are deposited in soils by atmospheric input and the use of mineral fertilizers or compost, and sewage sludge disposal. Conventional remediation methods usually involve excavation and removal of contaminated soil layer, physiccal stabilization (mixing of soil with cement, lime, apa- tite etc.), and washing of contaminated soils with strong acids or HM chelators [6]. However, if no remediation action is undertaken, the availability of arable land for cultivation will decrease, because of stricter environmental laws limiting food production on contaminated lands. Inorganic and organic contaminants typically found in urban areas are heavy metals and petroleum derived products. The presence of both types of contaminants on the same site presents technical and economic challenges for decontamination strategies.

Bioremediation, i.e. the use of living organisms to manage or remediate polluted soils, is an emerging technology. It is defined as the elimination, attenuation or transformation of polluting or contaminating substances by the use of biological processes. Initially, bioremediation employed microorganisms to degrade organic pollutants [7]. Microorganisms have been used since 600 B.C. by the Romans and others to treat the wastewater. The first commercial use of a bioremediation system was in 1972 to clean up a Sun Oil pipeline spill in Ambler, Pennsylvania [8]. Since 1972, bioremediation has be- 
come a well-developed way of cleaning up different contaminants. But ever since the use of green plants was proposed for in situ soil remediation phytoremediation has become an attractive topic of research and development [9]. As concluded by Anderson et al. [10], "understanding the mechanisms and critical factors influencing the plant-microbe-toxicant interaction in soils will permit more rapid realisation" of bioremediation of polluted soils. This review aims to contribute towards this goal by examining the current concepts and published data on the biological processes and major controls that may be used for their management in phytoremediation of inorganic and organic soil pollutants.

\section{Sources of Soil Pollution}

Trace metal contamination of soils can occur naturally from geological sources, for example $\mathrm{Cu}$ and $\mathrm{Ni}$ contamination of basaltic soils from the basalt parent material [11], or as a result of a wide ranges of industrial and agricultural activities. Therefore, trace metal pollution may harm human food safety and health, and there is much interest in the protection of unpolluted sites and the effective management of contaminated sites. Zinc is an essential plant nutrient and is one of the most ubiquitous trace metals in soils and it is often regarded as a potentially toxic element when present in excessive concentrations [12]. As chromium is widely used in many Industries of which leather industries are the biggest consumers, wastes from tanneries pose a serious threat to the environment. Metals and metalloids enter soils and wa- ters due to many processes including atmospheric deposition from industrial activities or power generation; disposal of wastes such as sewage sludge, animal manures, ash, domestic and industrial wastes or byproducts; irrigation and flood or seepage waters and the utilization of fertilizers, lime, or agrochemicals. Radionuclides are building up in some areas due to deliberate or accidental releases related to their use of energy production or for military purposes. It has been found that sewage sludge contents maximum amount of metals among different sources.

\section{Microbial Remediation of Soil Pollutants}

Microbes can reduced the activity of different types of metals or it can convert active forms of toxic metals to inactive forms by the processes as shown in Figure 1.

The choice of micro organisms to be used for bioremediation depends on availability of energy and carbon source, environmental conditions like temperatures, oxygen, moisture and the presence of hazardous contamninants. The aerobic bacteria recognized for their degradative abilities are Pseudomonas, Alcaligenes, Sphingomonas, Rhodococcus, and Mycobacterium (Table 1). These microbes have often been reported to degrade pesticides and hydrocarbons, both alkanes and polyaromatic compounds. Many of these bacteria use the contaminant as the sole source of carbon and energy. The contact between the bacteria and contaminant is a precondition for degradation. This is not easily achieved, as neither the microbes nor contaminants are uniformly spread in the

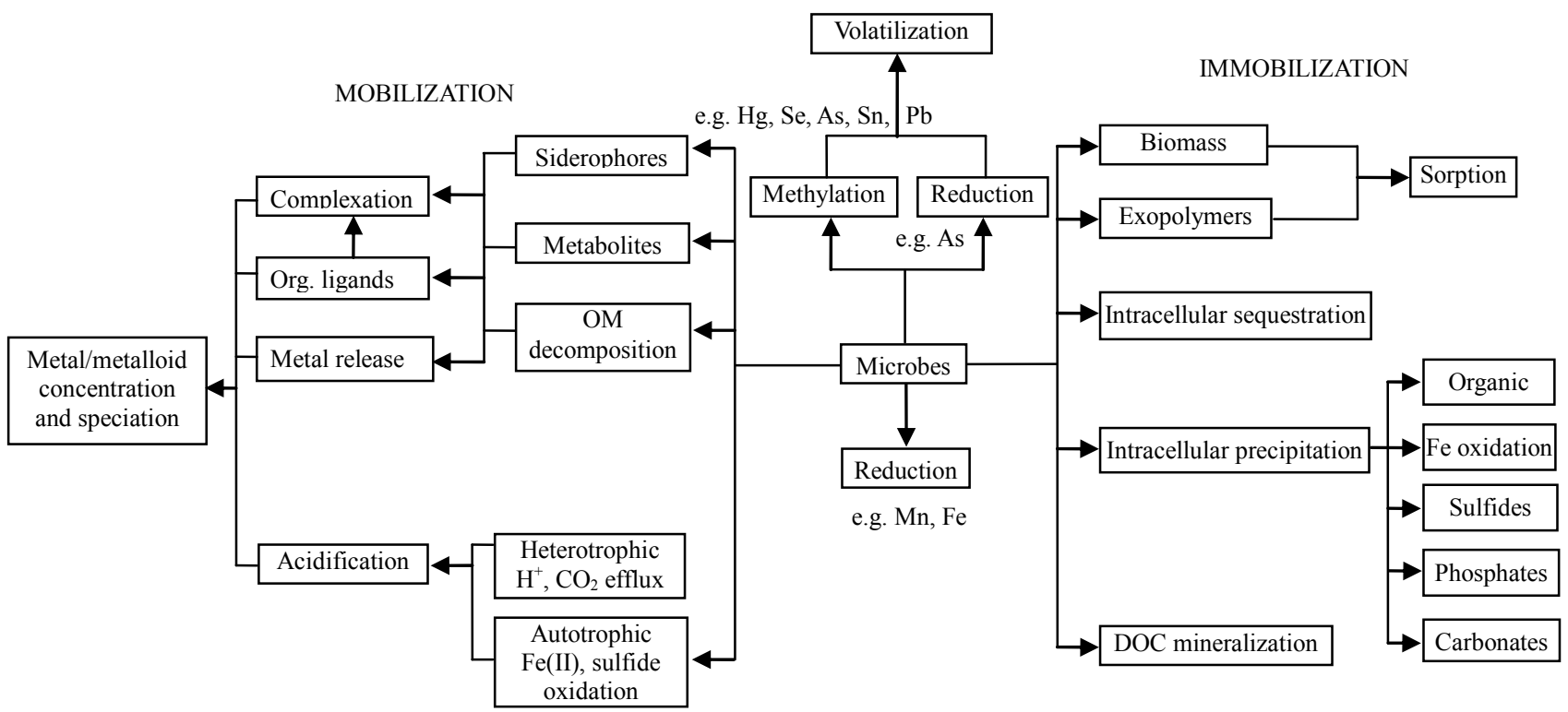

Figure 1. Processes involved in microbial mobilization and immobilization of metals and metalloids in soil (modified from Wengel [9]). 
soil. Some bacteria are mobile and exhibit a chemotactic response, sensing the contaminant and moving toward it. Other microbes such as fungi grow in a filamentous form toward the contaminant. It is possible to enhance the mobilization of the contaminant utilizing some surfactants such as sodium dodecyl sulphate. Substrates can be used to facilitate the contact between contaminants and microbes by enhancing the mobilization of contaminants (http://www.clu-in.org).

There is an increasing interest in anaerobic bacteria used for bioremediation of polychlorinated biphenyls in river sediments, dechlorination of the solvent trichloroethylene, and chloroform. Ligninolytic fungi, such as the white rot fungus Phanaerochaete chrysosporium have the ability to degrade an extremely diverse range of persistent or toxic environmental pollutants. Common substrates used include straw, saw dust, or corn cobs. Methylotrophs are the aerobic bacteria that grow by utilizing methane for carbon and energy. The initial enzyme in the pathway for aerobic degradation, methane monooxygenase, has a broad substrate range and is active against a wide range of compounds, including the chlorinated aliphatic trichloroethylene and 1,2-dichloroethane.

\section{Bioremediation Strategies}

Different bioremediation techniques are employed depending on the degree of saturation and aeration of an area. In situ techniques are defined as those that are applied to soil and groundwater at the site with minimal disturbance, whereas ex situ techniques are applied to at the site which has been removed via excavation (soil) or pumping (water) (Table 2).

\subsection{In Situ Bioremediation}

These techniques are generally the most desirable options due to lower cost and fewer disturbances since they provide the treatment in place avoiding excavation and transport of contaminants (http://www.epa.gov/tio). In situ treatment is limited by the depth of the soil that can be effectively treated. In many soils effective oxygen diffusion for desirable rates of bioremediation extend to a range of only a few centimeters to about $30 \mathrm{~cm}$ into the soil, although depths of $60 \mathrm{~cm}$ and greater have been effectively treated in some cases. The most important in situ land treatments are bioventing, in situ biodegradation, biosparging and bioaugmentation.

Table 1. Miroorganisms capable of degrading heavy metals.

\begin{tabular}{|c|c|c|}
\hline Heavy metal & Microorganisms & References \\
\hline $\mathrm{Cr}$ & $\begin{array}{l}\text { - } \quad \text { Pseudomonas fluorescens } \\
\text { - } \quad \text { Pseudomonas aeruginosa } \\
\text { - } \quad \text { Pseudomonas mendocina } \\
\text { - Enterobacter cloacae. }\end{array}$ & $\begin{array}{l}{[25]} \\
{[26]} \\
{[27]} \\
{[112]}\end{array}$ \\
\hline $\mathrm{Ni}$ & $\begin{array}{ll}\text { - } & \text { Pseudomonas } \\
\text { - } & \text { Methylobacterium, Rhodococcus and Okibacterium }\end{array}$ & $\begin{array}{l}{[29]} \\
{[14]}\end{array}$ \\
\hline $\mathrm{Se}$ & - $\quad$ Stenotrophomonas sp & {$[31]$} \\
\hline $\mathrm{U}$ & - $\quad$ Glomus intraradices took & {$[35]$} \\
\hline $\mathrm{Zn}, \mathrm{Cd}$ and $\mathrm{Mn}$ & - $\quad$ Arbuscular mycorrhizae & {$[40-47]$} \\
\hline
\end{tabular}

Table 2. Summary of bioremediation strategies.

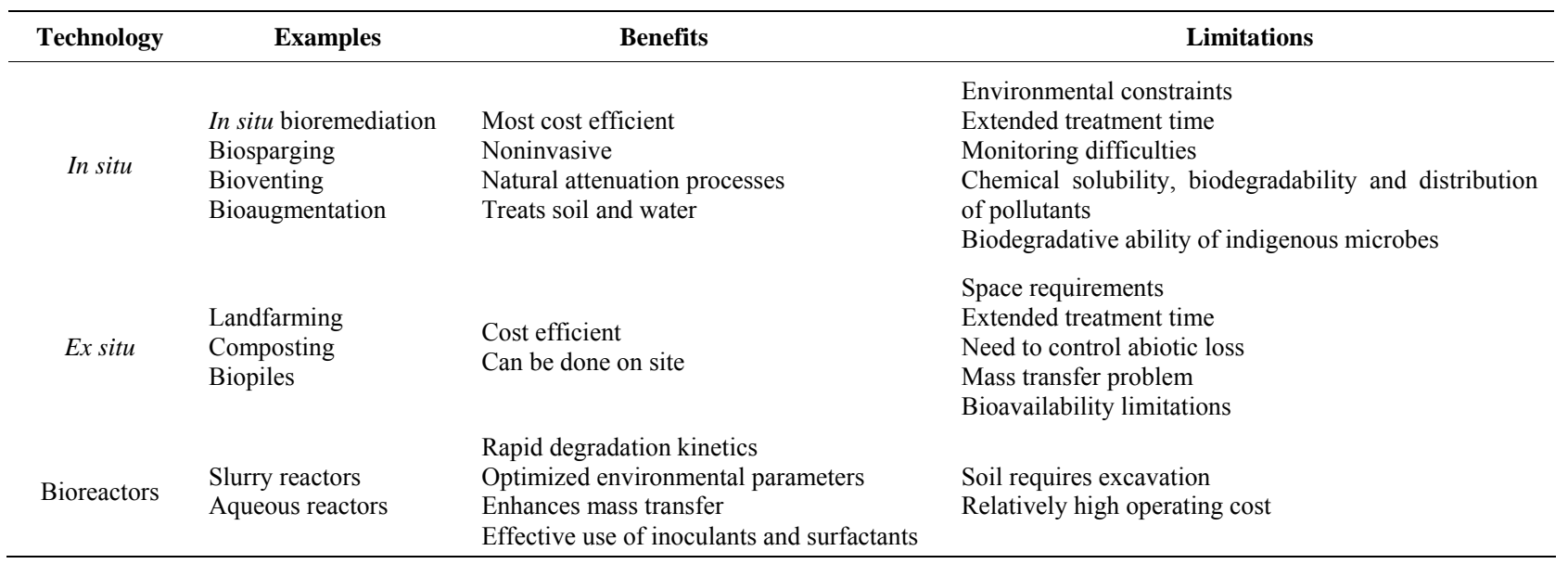


Bioventing is the most common in situ treatment and involves supplying air and nutrients through wells to contaminated soil to stimulate the indigenous bacteria. Bioventing employs low air flow rates and provides only the amount of oxygen necessary for the biodegradation while minimizing volatilization and release of contaminants to the atmosphere. It works for simple hydrocarbons and can be used where the contamination is deep under the surface.

In situ biodegradation involves supplying oxygen and nutrients by circulating aqueous solutions through contaminated soils to stimulate naturally occurring bacteria to degrade organic contaminants. Generally, this technique includes conditions such as the infiltration of water-containing nutrients and oxygen or other electron acceptors for groundwater treatment.

Biosparging involves the injection of air under pressure below the water table to increase groundwater oxygen concentrations and enhance the rate of biological degradation of contaminants by naturally occurring bacteria. Biosparging increases the mixing in the saturated zone and thereby increases the contact between soil and groundwater.

Bioaugmentation involves the addition of microorganisms indigenous or exogenous to the contaminated sites to enhance the degradation of the contaminants.

\subsection{Ex Situ Bioremediation}

These techniques involve the excavation or removal of contaminated soil from ground. The most important exsitu treatments are landfarming, composting, biopiles and bioreactors.

Landfarming is a simple technique in which contaminated soil is excavated and spread over a prepared bed and periodically tilled until pollutants are degraded. The goal is to stimulate indigenous biodegradative microorganisms and facilitate the aerobic degradation of contaminants. The practice is limited to the treatment of superficial $10-35 \mathrm{~cm}$ of soil. Since landfarming has the potential to reduce monitoring and maintenance costs, as well as clean-up abilities, it has received much attention as a disposal alternative.

Is a technique that involves combining contaminated soil with nonhazardous organic amendments such as manure or agricultural wastes. The presence of these organic materials supports the development of a rich microbial population and elevated temperature characteristics of composting.

Biopiles are a hybrid of landfarming and composting, typically used for treatment of surface contamination with petroleum hydrocarbons [13]. They are a refined version of landfarming that tend to control physical losses of the contaminants by leaching and volatilization. Bio- piles provide a favorable environment for indigenous aerobic and anaerobic microorganisms.

Bioreactors. Slurry reactors or aqueous reactors are used for ex situ treatment of contaminated soil and water pumped up from a contaminated plume. Bioremediation in reactors involves the processing of contaminated solid material (soil, sediment, sludge) or water through an engineered containment system. A slurry bioreactor is a containment vessel and apparatus used to create a threephase (solid, liquid, and gas) mixing condition to increase the bioremediation rate of soilbound and watersoluble pollutants as a water slurry of the contaminated soil and biomass (usually indigenous microorganisms) capable of degrading target contaminants. In general, the rate and extent of biodegradation are greater in a bioreactor system than in situ or in solid-phase systems because the contained environment is more manageable and hence more controllable and predictable.

\section{Role of Bacteria in Bioremediation}

\subsection{Rhizosphere Bacteria Affect Plant Growth and Metal Uptake}

There is increasing evidence that rhizosphere bacteria contribute to the metal extraction process (Table 3), but the mechanisms of this plant-microbe interaction are yet to be fully understood. The rhizosphere of heavy metal accumulating plants provides a niche for adapted metal resistant microorganisms [14,15] and the mobility of heavy metals is higher in the rhizosphere of metal accumulators than in bulk soil, due to active mobilization by roots and microorganisms [16]. Bacterial IAA, ACC deaminase, siderophores, organic acids or specific ligands have been associated with enhanced growth and accumulation and mobilization of heavy metals under heavy metal exposure [17-19].

The rhizosphere bacteria of Salix caprea were reported to influence metal mobilization and uptake. Experimental results indicated that plant growth promotion might be an important parameter besides the enhancement of metal uptake. Zinc resistances of the Salix caprea rhizosphere bacteria ranged between 2 and $11 \mathrm{mM}$ and were much higher than those of bacteria associated with $\mathrm{Zn}$ hyperaccumulating Thlaspi. This suggests a high bioavailability of $\mathrm{Zn}$ in the rhizosphere of Salix caprea and a specific adaptation of the associated bacteria. Salix caprea trees growing at the contaminated site in Arnoldstein were found to accumulate higher amount of $\mathrm{Zn}$ and $\mathrm{Cd}$, but less $\mathrm{Pb}$ which indicates the relatively low $\mathrm{Pb}$ tolerance of the bacteria [15]. The possible mechanisms of microbial uptake and detoxification of toxic metals in soil matrix is presented in Figure 2. 
Table 3. Overview of phytoremediation applications.

\begin{tabular}{|c|c|c|}
\hline Technique & Plant mechanism & Surface reacting medium \\
\hline Phytoextraction & $\begin{array}{l}\text { Concentration of metal into the plant tissue via direct uptake } \\
\text { with subsequent removal of the plant }\end{array}$ & Soils \\
\hline Phytotransformation & Plant uptake and degradation of organic compounds & Surface water, ground water \\
\hline Phytostabilization & $\begin{array}{l}\text { Root exudates cause metals to precipitate and become less } \\
\text { available }\end{array}$ & Soils, ground water, mine tailing \\
\hline Phytodegradation & Enhances microbial degradation in rhizosphere & Soils, groundwater within rhizosphere \\
\hline Rhizo filtration & Uptake of metals into plant roots & Soils, Surface water \\
\hline Phytovolatilization & $\begin{array}{l}\text { Plants evaporate selenium, mercury and volatile hydrocar- } \\
\text { bons }\end{array}$ & Soils, ground water \\
\hline
\end{tabular}

Cell membrane/ periplasmic space
Adsorption/ion exchange
Redox reactions/transformations
Precipitation
Diffusion and transport (influx and efflux)

Figure 2. The microbial uptake and detoxification of toxic metals.

\subsection{Chromium in the Environment: Factors Affecting Biological Remediation}

The detoxification of chromium in soil is based on the fact that $\mathrm{Cr}(\mathrm{VI})$ is readily reduced to $\mathrm{Cr}(\mathrm{III})$ and immobilized in organic matter rich soils. The use of $\mathrm{Cr}(\mathrm{VI})-$ contaminated groundwater to irrigate organic matter rich soil based on the mechanism of reduction and precipitation of $\mathrm{Cr}$ in the soil as $\mathrm{Cr}$ (III) [20,21]. In a study to examine the processes responsible for $\mathrm{Cr}(\mathrm{VI})$ reduction in soil, it was reported that organic matter content, bioactivity, and oxygen status were among the important factors [21]. Under aerobic, field-moist conditions, organic matter rich soil (amended with 50 tons $\mathrm{ha}^{-1}$ organic matter) was reported to reduce $96 \%$ of added $\mathrm{Cr}(\mathrm{VI})$, whereas sterile soils receiving similar amendments reduced only $75 \%$ of the original $\mathrm{Cr}(\mathrm{VI})$, demonstrating the impor- tance of the presence of soil microorganisms in conjunction with a readily available carbon source. These studies assert that soil organic matters play a key role in reduction of $\mathrm{Cr}(\mathrm{VI})$ to $\mathrm{Cr}(\mathrm{III})$. Organic matter enhances the reduction of chromate in soil by increasing microbial activities, acting as electron donors, and by lowering the O2 level of the soil, thus creating reducing conditions.

Realizing the potential importance of soil microorganisms in reducing $\mathrm{Cr}(\mathrm{VI})$ in contaminated soils, several groups attempted to identify and isolate microorganisms that can mediate the reduction of $\mathrm{Cr}(\mathrm{VI})$ to $\mathrm{Cr}(\mathrm{III})$ in soils [22,23]). These microorganisms thought to be $\mathrm{Cr}$ resistant as well since the reduction rate is slower than the uptake rate [24]. Some of the bacterial strains found to be resistant to high levels of $\mathrm{Cr}(\mathrm{VI})$ include Pseudomonas fluorescens [25], P. aeruginosa [26], and Pseu- 
domonas mendocina [27]. Bacterial populations resistant to as much as $500 \mathrm{mg} \mathrm{L}^{-1} \mathrm{Cr}(\mathrm{VI})$ and fungal populations resistant to $1000 \mathrm{mg} \mathrm{L}^{-1} \mathrm{Cr}(\mathrm{VI})$ were directly isolated from soils [28].

\subsection{Nickel Tolerance and Accumulation by Bacteria from Rhizosphere of Nickel Hyperaccumulators}

The bacteria in the rhizosphere of Ni-hyperaccumulators are capable of tolerating high concentration of $\mathrm{Ni}$ and also possess nickel uptake potential. The Ni-hyperaccumulators in combination with these Ni-resistant bacteria could be an ideal tool for nickel bioremediation. This high concentration of bioaccessible nickel in the rhizosphere of Ni-hyperaccumulators in turn provides a niche for nickel-resistant microflora.

The predominant Ni-resistant bacteria belonged to Pseudomonas in the rhizosphere of Ni-hyperaccumulator, Alyssum bertolonii [29], while the same under Thlaspi goesingense were identified as Methylobacterium, Rhodococcus and Okibacterium [14]. The rhizosphere of Rinorea bengalensis and Dichapetalum gelonioides ssp. andamanicum, the endemic Ni-hyperaccumulators from serpentines of Andaman harbor Ni-resistant bacteria, which are capable of accumulating nickel and could tolerate $>8 \mathrm{mM} \mathrm{Ni}$ and viable cells were capable of accumulating Ni from aqueous solution. This may be attributed to the presence of Ni-binding sites on the cell surface of metallophiles [30].

\subsection{Improvement of Selenite and Selenate Abatement in Selenium Contaminated Soils through Rhizospheric Bacterial Population}

Brassica juncea cultivation on the soil has been found to result in a higher volatilisation rate when compared with non-vegetated soil. However, the presence of $B$. juncea in soil amended with selenium as selenite or selenate has revealed to promote a significant Se precipitation by eliciting rhizobacteria (Stenotrophomonas $s p$ ) capable of reducing the metalloid oxyanions to $\mathrm{SeO}$. In fact, the capacity of certain rhizobacteria to precipitate Se oxyanions, reducing their toxicity in contaminated matrices, could be seen as an alternative option to Se phytoextraction or phytovolatilisation, so far emphasized for the removal of the toxic metalloid from soil. B. juncea efficiently accumulates as well as volatilizes selenium [31]). Thus, the rhizosphere of $B$. juncea resulted to be an effective source and carrier of microorganisms capable to in vitro reduction and precipitation of toxic $\mathrm{Se}(\mathrm{IV})$ and $\mathrm{Se}(\mathrm{VI})$ to non toxic elemental Selenium volatilisation by $B$. juncea has been confirmed as a relevant mechanism of Se detoxification in contaminated soil.

\section{Role of Arbuscular Mycorrhiza in Bioremediation}

\subsection{Effects of the Mycorrhizal Fungus Glomus intraradices on Uranium Uptake and Accumulation in Uranium-Contaminated Soil}

Arbuscular mycorrhizae (AM) are ubiquitous symbiotic associations between higher plants and soil fungi [32] and their extraradical mycelium form bridges between plant roots and soil, and mediate the transfer of various elements into plants. There is also a growing body of evidence that arbuscular mycorrhizal fungi can exert protective effects on host plants under conditions of soil metal contamination. Binding of metals in mycorrhizal structures and immobilization of metals in the mycorrhizosphere may contribute to the direct effects. Indirect effects may include the mycorrhizal contribution to balanced plant mineral nutrition, especially $\mathrm{P}$ nutrition, leading to increased plant growth and enhanced metal tolerance. It has been widely reported that ectomycorrhizal and ericoid mycorrhizal fungi can increase the tolerance of their host plants to heavy metals when the metals are present at toxic levels. The underlying mechanism is thought to be the binding capacity of fungal hyphae to metals in the roots or in the rhizosphere which immobilizes the metals in or near the roots and thus depresses their translocation to the shoots [22,33]. Being strongly adsorbed and bound by mycorrhizal structures, metals in soils may be retained within a certain volume of soil, with minimization of leaching processes and restriction of the zone of contamination, and plants may be protected from metal toxicity and environmental stress.

Arbuscular mycorrhizae may play an important role in plant adaptation to U contaminated soils by not only improving plant $\mathrm{P}$ acquisition ability, but also enhancing $\mathrm{U}$ immobilization by roots, thus reducing $U$ partitioning into plant shoots and environmental risks. As U behaviour in soil is similar to heavy metals such as $\mathrm{Pb}$, it can be deduced that mycorrhizal fungi, may have significant effects on $U$ mobilization and uptake $[34,35]$. It has been found that extraradical AM fungal mycelium of Glomus intraradices took up and translocated $U$ towards root in in vitro culture system [35], and hyphae were more efficient in U translocation compared with roots [36]. Soluble uranyl cations or uranyl-sulphate species that are stable under acidic conditions were translocated to a higher extent to roots through fungal tissues, while phosphate and hydroxyl species dominating under acidic to near neutral conditions or carbonate species dominating under alkaline conditions were rather immobilized by hyphal structures. It is documented that plant uptake of $U$ is affected by various factors, such as soil properties [37] and 
uranium-phosphorus interactions $[38,39]$.

\subsection{Arbuscular Mycorrhiza can Depress Translocation of Zinc to Shoots of Host Plants in Soils Moderately Polluted with Zinc}

It has been demonstrated that at high soil heavy metal concentrations, arbuscular mycorrhizal infection reduced the concentrations of $\mathrm{Zn}, \mathrm{Cd}$ and $\mathrm{Mn}$ in plant leaves [40, 41]. Field investigations have indicated that mycorrhizal fungi can colonize plant roots extensively even in metal contaminated sites [42-44], and $\mathrm{Zn}$ - and Cd-tolerant fungal strains have been isolated from contaminated sites by several research groups $[45,46]$. Numerous experimental studies have indicated that under conditions of moderate Zn contamination, arbuscular mycorrhizal plants may exhibit much lower shoot concentrations of $\mathrm{Zn}$ and higher plant yields than non-mycorrhizal controls, indicating a protective effect of mycorrhizas on the host plants against potential $\mathrm{Zn}$ toxicity [47].

\section{Advantages and Disadvantages of Bioremediation}

\subsection{Advantages}

1) Bioremediation is a natural process and is therefore perceived by the public as an acceptable waste treatment process for the complete destruction of a wide variety of contaminants.

2) The residues for the treatment are usually harmless products and include carbon dioxide, water, and cell biomass. Many compounds that are legally considered to be hazardous can be transformed to harmless products. This eliminates the chance of future liability associated with treatment and disposal of contaminated material.

3) Bioremediation can often be carried out on site, often without causing a major disruption of normal activeties. This also eliminates the need to transport quantities of waste off site and the potential threats to human health and the environment that can arise during transportation.

4) Bioremediation can prove less expensive than other technologies that are used for clean-up of hazardous waste.

\subsection{Disadvantages}

1) Bioremediation is limited to those compounds that are biodegradable. Not all compounds are susceptible to rapid and complete degradation.

2) Biological processes are often highly specific. Therefore, the success of the technique requires several site factors like the presence of metabolically capable microbial populations, suitable environmental growth conditions, and appropriate levels of nutrients and contaminants.
3) Research is needed to develop and engineer bioremediation technologies that are appropriate for sites with complex mixtures of contaminants that are not evenly dispersed in the environment.

4) Bioremediation often takes longer than other treatment options, such as excavation and removal of soil or incineration.

5) Regulatory uncertainty remains regarding acceptable performance criteria for bioremediation and there are no acceptable endpoints for bioremediation treatments.

6) There are some concerns that the products of biodegradation may be more persistent or toxic than the parent compound.

\section{Plant Assisted Bioremediation}

Phytoremediation may be defined as use of vegetation to contain, sequester, remove, or degrade organic and inorganic contaminants in soils, sediments, surface water and groundwater. Phytoremediation is an emerging technology that uses plants to remove contaminants from soil and water [48]. The basic idea that plant can be used for environmental remediation is very old and cannot be traced to any particular source. However, a series of fascinating scientific discoveries combined with an interdisciplinary research approach have allowed the development of this idea into a promising, cost-effective, and environmental friendly technology.

Although the application of microbial biotechnology has been successful with petroleum-based constituents, microbial digestion has met limited success for widespread residual organic and metals pollutants. Vegetation- based remediation shows potential for accumulating, immobilizing, and transforming a low level of persistent contaminants. We can find five types of phytoremediation techniques, classified based on the contaminant fate: phytoextraction, phytotransformation, phytostabilization, phytodegradation, rhizofiltration, even if a combination of these can be found in nature (Table 3).

Phytoextraction or phytoaccumulation: This is a process used by the plants to accumulate contaminants into the roots and aboveground shoots or leaves. This technique saves tremendous remediation cost by accumulating low levels of contaminants from a widespread area. Unlike the degradation mechanisms, this process produces a mass of plants and contaminants (usually metals) that can be then harvested, incinerated, and the ash related to a confined area or the heavy metals are extracted from it (Figure 3, [49]).

Phytostabilization is a technique in which plants reduce the mobility and migration of contaminated soil. Leachable constituents are adsorbed and bound into the plant structure so that they form a stable mass of plant 


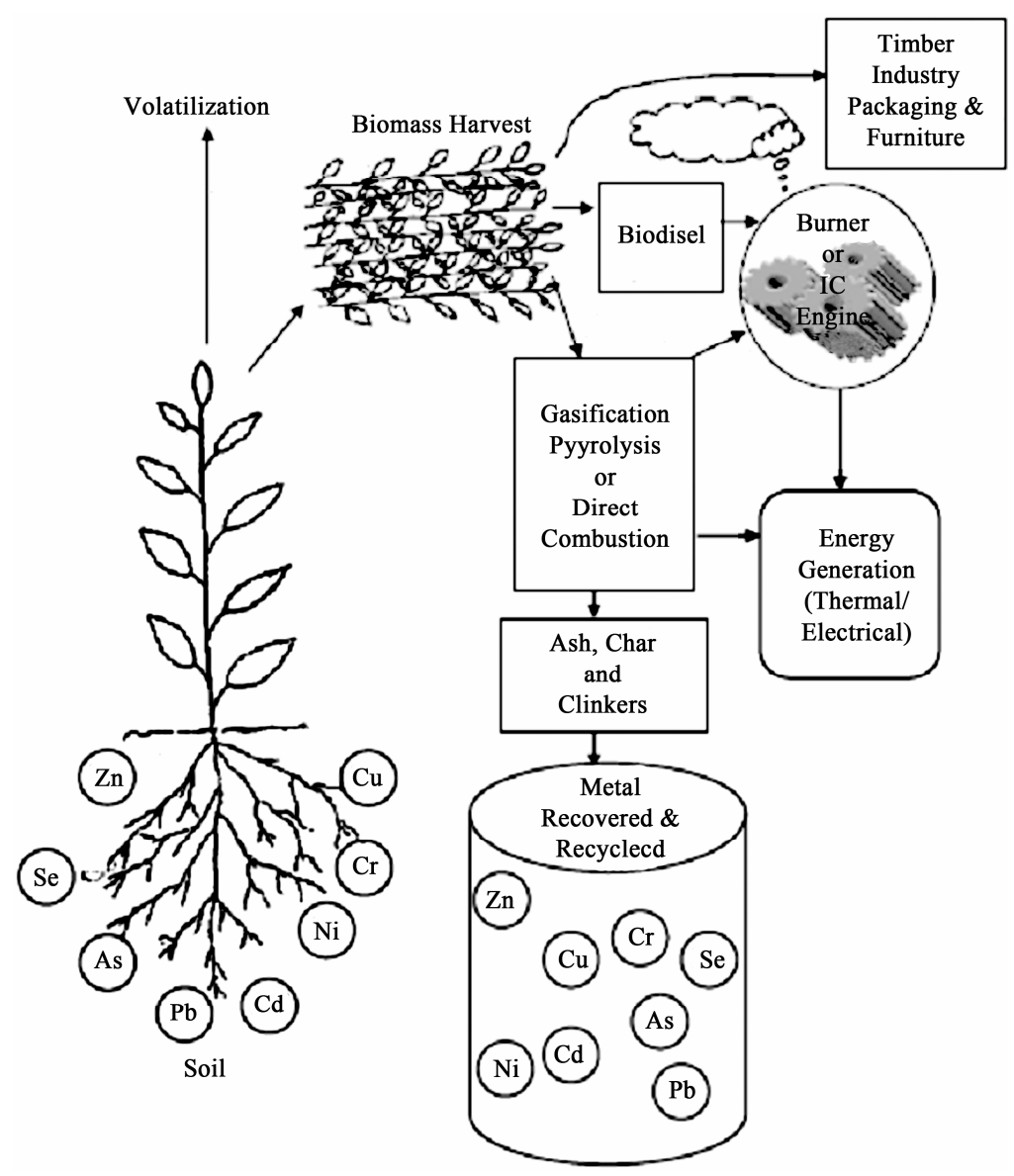

Figure 3. Phytoextraction of metals from soil and their utilization [49].

from which the contaminants will not reenter the environment.

Phytodegradation or rhizodegradation is the breakdown of contaminants through the activity existing in the rhizosphere due to the presence of proteins and enzymes produced by the plants or by soil organisms such as bacteria, yeast, and fungi. Rhizodegradation is a symbiotic relationship where the plants provide nutrients necessary for the microbes to thrive, while microbes provide a healthier soil environment.

Rhizofiltration is a water remediation technique that involves the uptake of contaminants by plant roots. Rhizofiltration is used to reduce contamination in natural wetlands and estuary areas. In Table we can see an overview of phytoremediation applications.

\subsection{Phytoextraction}

Phytoextraction employs metal hyperaccumulator plant species to transport high quantities of metals from soils into the harvestable parts of roots and aboveground shoots [50,51]. Phytoextraction is an innovative, novel and potentially inexpensive technology (Table 4) using higher plants for in situ decontamination of metal-polluted soils, sludges and sediments [52-55]. Large biomass production and high rates of metal uptake and translocation into shoots are critical to achieve reasonable metal extraction rates. Effective phytoextraction requires both plant genetic ability and the development of optimal agronomic management practices [1,56]. Hyper accumulators are defined as plants that contain in their tissue more than $1,000 \mathrm{mg} \mathrm{kg}^{-1}$ dry weight of $\mathrm{Ni}, \mathrm{Co}, \mathrm{Cu}, \mathrm{Cr}$, $\mathrm{Pb}$, or more than $10,000 \mathrm{mg} \mathrm{kg}^{-1}$ dry weight of $\mathrm{Zn}$, or $\mathrm{Mn}$ [6]. Apart from metal tolerance, hyper accumulation is thought to benefit the plant by means of allelopathy, defense against herbivores, or general pathogen resistance [57-59].

In-situ phytoextraction of $\mathrm{Ni}$ by a native population of Alyssum murale on an ultramafic site (Albania) have been reported by Bani et al., [60]. In the case of phytomining, the use of native flora (including local populations of hyperaccumulators) with limited agronomic practices (extensive phytoextraction) could be an alternative to intensively managed crops. Ebbs et al. [61] showed that $T$. caerulescens (UK) could achieve approximately 
Table 4. Phytoremediation of heavy metals.

\begin{tabular}{crlr}
\hline Heavy metal & & \multicolumn{1}{c}{ Plant species } & References \\
\hline $\mathrm{Zn}$ and $\mathrm{Cd}$ & $\bullet$ & Salix caprea & {$[15]$} \\
$\mathrm{Ni}$ & $\bullet$ & Alyssum bertolonii & {$[29]$} \\
& $\bullet$ & $\begin{array}{l}\text { Thlaspi goesingense } \\
\text { Rinorea bengalensis and Dichapetalum gelonioides ssp. andamanicum }\end{array}$ & {$[14]$} \\
$\mathrm{Se}$ & $\bullet$ & Brassica juncea & {$[31]$} \\
$\mathrm{Ni}$ & - & Alyssum murale & {$[60]$} \\
$\mathrm{Cd}$ & - & T.caerulescens, Brassica spp. \\
$\mathrm{Cs}$ & - & Red root pigweed, Indian mustard, tepary bean & {$[61]$} \\
\hline
\end{tabular}

10 times higher shoot $\mathrm{Cd}$ concentration as compared to Brassica spp. Lasat et al. [62] conducted a field study to investigate the potential of three plant species for phytoremediation of a ${ }^{137} \mathrm{Cs}$-contaminated site. Approximately 40 -fold more ${ }^{137} \mathrm{Cs}$ was removed from the contaminated soil in shoots of red root pigweed than in those Indian mustard and tepary bean. The greater potential for ${ }^{137} \mathrm{Cs}$ removal from the soil by red root pigweed was associated with both high concentration of ${ }^{137} \mathrm{Cs}$ in shoot and high shoot-biomass production. Among the plants, Urtica dioica found to be very effective due to its higher uptake capacity for chromium. Zea mays showed high tolerance towards $\mathrm{Cr}$ with negligible concentration in leaves. Due to its higher Cr uptake and low biomass production Urtica dioica, commonly known as 'stinging nettle', in German 'Brennnessel', can be considered as the right plant for remediation of $\mathrm{Cr}$ contaminated sites. As nettle grows both in tropical and cold climates, therefore its value as 'nature cleaner' is universal.

The lack of success of phytoremediation is largely related to the small biomass of most true hyperaccumulator plants or to metal accumulation by high-biomass (crop) plants being too low. For example while contaminant mixtures appear to be the rule rather than the exception at polluted sites, metal tolerance, as well as efficient metal accumulation by a given plant species is typically restricted to one or few elements. Moreover, high metal/ metalloid uptake rates in plants as required for phytoextraction can only be achieved if the metal/metalloid activity in the rhizosphere soil solution is sustained by rapid re-supply from the solid phase $[63,64]$. The most studied approach is chelant-assisted phytoextraction using EDTA and other artificial chelants. Other researchers have employed acidifying amendments such as elemental sulphur $[65,66]$ and ammonium fertilization along with nitrification inhibitors $[67,68]$ to enhance metal mobility in the rhizosphere of phytoextraction crops. Co-cropping of different plant species has been proposed as a strategy to increase metal bioavailability [69] and to better ex- plore the soil volume and address the heterogeneous distribution of pollutants in field soils [70], for instance by combining deep rooting metal accumulating willows with small hyperaccumulator species that can efficiently explore the uppermost soil horizons. Co-cropping of metal accumulators with alder trees (Alnus sp.) may offer an interesting alternative to chemical mobilisation of metals in phytoextraction crops [71]. Alder species are associated with $\mathrm{N}_{2}$-fixing actinorhizal symbionts (Frankiae). Nitrogen fixation has been shown to result in substantial acidification in alder rhizospheres [72] because nitrogen uptake relying on $\mathrm{N}_{2}$-fixation rather than anionic nitrate results in enhanced proton exudation to maintain the cation-anion balance [73]. These indigenous processes could be used to increase metal bioavailability to cocropped metal accumulators and to improve nitrogen nutrition. Another interesting approach to enhance pollutant tolerance, plant performance and accumulation of metals at root surfaces using recombinant rhizobacterium Pseudomonas putida expressing a metal-binding peptide (E20) was recently demonstrated in hydroponic culture by Wu et al. [74].

\subsection{Phytoremediation of Heavy Metal-Contaminated Soils: Natural Hyperaccumulation versus Chemically Enhanced Phytoextraction}

Recent research has shown that chemical amendments, such as synthetic organic chelates, can enhance phytoextraction by increasing HMs bioavailability in soil thus enhancing plant uptake, and translocation of HMs from the roots to the green parts of tested plants $[42,75,76]$. Of the chelates tested, ethylene diamine tetraacetic acid (EDTA) was often found to be the most effective [77,78]. Huang et al. [76] found that among different chelating agent EDTA is more effective in accumulation $\mathrm{Pb}$ in corn and pea and also found that on increasing the concentration of EDTA accumulation efficiency of $\mathrm{Pb}$ in shoot of 
corn and pea was increased Therefore, the potential risks of use of EDTA or other chelators for phytoextraction should be thoroughly evaluated before steps towards further development and commercialization of this remediation technology are attempted. Research (reference) indicated up to 104.6, 2.3 and 3.2-fold increase of $\mathrm{Pb}, \mathrm{Cd}$ and $\mathrm{Zn}$ concentration, respectively, in leaves of Chinese cabbage grown on EDTA $\left(10 \mathrm{mmol} \mathrm{kg}{ }^{-1}\right)$ treated soil. EDTA effectively prevents cell wall retention of HM and influenced not only HM uptake but also enhanced HM translocation in the plant [77]. The use of chelates as soil amendments to increase the bioavailability of HM has raised some concern over the potential increased mobility of the metalchelate complex in the soil. Several authors have emphasized the possibility of HM groundwater contamination or other off site migrations [79]. The adverse effects of HMs on the occurrence of arbuscular mycorrhizal fungi, HM tolerance in these micro-organisms, and their effects on metal uptake and transfer to plants are well documented [80]. There is, however, very little information on the direct effects of EDTA on arbuscular mycorrhiza [81]. The toxicity of EDTA on soil bacteria, actinomycetes and fungi was studied with PLFA and DGFA methods. PLFA and DGFA are relatively new tools in environmental microbiology and enable the insight into the structure of microbial populations in complex substrates, and give an indication of environmental stress inflicted on microbial populations [82]. The results are in accord with phytotoxicity and arbuscular mycorrhize tests. Increasing doses of EDTA increased the cultural stress (DGFA analysis, trans/cis ratio of PLFA methyl esters) of soil microflora. The PLFA results indicated that soil fungi are more sensitive to EDTA or to EDTA mediated increase of HMs bioavailability than are soil bacteria and actinomycetes. This can be partly explained by a very diverse bacterial metabolism which enables bacterial species to adjust to different environmental conditions. Therefore, emphasize the importance of EDTA risk assessment for each specific soil and phytoextraction conditions. New non-toxic chelates, and methods to prevent the leaching of the HMs-chelate complex down the soil profile need to be evaluated.

\subsection{Rhizovolatilisation}

Rhizovolatilisation of inorganic contaminants differs significantly from other remediation techniques as it releases the contaminants in the atmosphere. In the case of selenium, volatile methylated species are less toxic than inorganic forms [83]. The concern related to volatilisation of contaminants is significant especially for elements such as mercury and arsenic, which are not essential and can form extremely toxic volatile compounds [84]. Elemental mercury is far less toxic than methylmercury and its half-life in the atmosphere is in the order of years which should enable a substantial dilution into the large atmospheric pool [85]. For this reason an approach based on the accumulation of $\mathrm{Hg}^{2+}$ in the plant shoot rather than volatilisation of elemental mercury has been pro- posed as an alternative strategy [86]. Studies on arsenic uptake and distribution in higher plants indicate that ar- senic predominantly accumulated in root and only small quantities are transported to shoots. However, plant may enhance the biotransformation of arsenic by rhizospheric bacteria, thus increasing rates of volatilization.

\subsection{Rhizodegradation}

Field-contaminated soils that have undergone prolonged periods of ageing [87-91] generally appear to be much less responsive to rhizodegradation than fresh soil [9298]. Characterising root exudation in terms of chemical composition and quantity and investigation of utilization pattern by microbial strains competent to degrade organic pollutants is a prerequisite for this purpose. In long-term field contaminated soil, enhancement of bioavailability appears to be the key of successful biodegradation. Selection and engineering of plants and microbial strains that can modify solubility and transport of organic pollutants through exudation of biosurfactants holds promise [99]. Recent attempts to genetically engineer plant- microbial systems to enhance rhizodegradation include gene cloning of plants containing bacterial enzymes for the degradation of organic pollutants such as PCBs and of recombinant, root-colonising bacteria (e.g. Pseudomonas fluorescens) expressing degradative enzymes (e.g. ortho-monooxygenase for toluene degradation) [100].

Soils and sediments polluted with crude oil hydrocarbons are of major environmental concern on various contaminated sites. Hydrocarbon-degrading microorganisms are ubiquitously distributed in soils and constitute less than $1 \%$ of the total microbial communities but may increase to $10 \%$ in the presence of crude oil [101]. Degradation of $\mathrm{HC}$ further requires a balanced nutrient supply in soil which can be achieved by fertilisation (biostimulation). Mainly nitrogen and, to a lesser extent, phosphorus are reported to be limiting factors of $\mathrm{HC}$ degradation processes in oxic soil environments [102104]. Microorganisms are able to use $\mathrm{HC}$ as a carbon and energy source [103] preferentially in the absence of a readily available carbon source like labile natural organic matter. Read et al. [105] observed increased phosphorus mobilisation due to exudation of biosurfactants by lupine (Lupinus angustifolius L. cv. Merrit). The identified biosurfactants consisted of phospholipids which could provide an additional phosphorus source to microorganisms. Polycyclic aromatic hydrocarbons (PAHs) are contaminants generated from many sources such as the 
combustion of coal and fossil fuels for energy production and are potential carcinogens that can induce mutations. As lipophilic compounds, they present a significant health risk if they enter the food chain [106]. These compounds can be used by soil microorganisms as an energy and carbon source, although four-, five-, and six-ring PAHs are more resistant to biodegradation. Bacteria initiate PAH degradation via dioxygenase attack, increasing PAH chemical reactivity and solubility [107].

\subsection{Phytostabilisation/Phytoimmobilisation}

Inoculation with metal-resistant PGPR can support the establishment and improve vitality of the phytostabilisation crops, and detoxification mechanisms in the rhizosphere may be enhanced by inoculation with microbial associates. Some plants and microorganisms are able to precipitate metal compounds in the rhizosphere. This was shown for lead pyromorphite $[108,109]$, and may provide an effective means to reduce metal toxicity as well as metal mobility (phytoimmobilisation) [110]. The design of phytostabilisation systems relates to combining different approaches to ameliorate multiple constraints (i.e., nutrient and water deficiency, toxicity due to mixed contamination) and to control their efficiency in field conditions. The combined use of alders, frankiae and mycorrhizae for the remediation of contaminated ecosystems is thought to improve plant nutrition through both the actinorhizal symbiosis (Frankiae) and the mycorrhizal symbioses, and to protect the plant from toxicity through the mechanisms discussed above for metals and organic pollutants [71].

\subsection{Advantages and Disadvantages of Phytoremediation}

Phytoremediation is well suited for use at very large field sites where other methods of remediation are not cost effective or practicable; at sites with a low concentration of contaminants where only polish treatment is required over long periods of time and in conjunction with other technologies where vegetation is used as a final cap and closure of the site. There are some limitations to the technology which include long duration of time for remediation, potential contamination of the vegetation and food chain and difficulty in establishing and maintaining vegetation at some sites with high toxic levels.

\subsection{Integrated Approaches}

The complexity and heterogeneity of sites often polluted with multiple metals, metalloids and organic compounds requires the design of integrated phytoremediation systems that combine different processes and approaches. Co-cropping different species may enhance the overall capabilities of a phytoremediation system to explore the contaminated soil volume, address different pollutants, and support differential microbial consortia in their rhizospheres. Shared rhizospheres may be designed to optimise the nutritional status, e.g. by combining plants that support $\mathrm{N}_{2}$-fixing and P-solubilising microorganisms. Co-cropping could be also used to modify the bioavailability of pollutants, e.g. by combining Alnus sp. with metal-accumulating willows [71] or to combine metal phytoextraction crops (e.g. willows) with plants that support rhizodegradation of organic pollutants (e.g. grasses). Engineering rhizobacteria capable of heavy metal accumulation and enhanced degradation of organic pollutants such as trichloroethylene offers further opportunities to address multiple contaminated sites [111]. While some phyto-/rhizoremediation technologies are being used commercially, it is obvious that the complexity of interactions in the plant-microbe-soil pollutant system requires substantial further research efforts to improve our understanding of the rhizosphere processes involved.

\section{Conclusion and Future Research Needs}

It can be concluded that bioremediation is indeed an environmentally friendly, gentle management option for polluted soil as it uses solar-driven biological processes to treat the pollutant. The success of a phytoextraction technique is largely dependent on the continuous availability of the metal of interest to the phytoextracting plants. It appears attractive because in contrast to most other remediation technologies, it is not invasive and, in principle, delivers intact, biologically active soil. There is a need to enhance research efforts on this emerging and environmentally friendly "green" technology. Research should focus on identifying remediating plants that are adapted to the local climate and soil conditions.

As phytoremediation is a slow process, biotechnologycal as well as classical hybridization techniques should be used to develop more efficient metal hyperaccumulator plant species having increasing pollutant tolerance, root and shoot biomass, root architecture and morphology, pollutant uptake properties, and degradation capabilities for organic pollutants etc. [9].

Other approaches to be the management of microbial consortia: the selection and engineering of microorganisms with capabilities for pollutant degradation, beneficial effects on the phytoremediation crops, or modifying effects on pollutant bioavailability. Selection and engineering of plants and microbial strains that can modify solubility and transport of organic pollutants through exudation of biosurfactants holds a great promise [99].

Additional strategies should include proper management of the soil, e.g. via fertilisation or chelant addition to increase pollutant bioavailability, and of the phytore- 
mediation crops, e.g. via optimisation of coppicing, harvest cycles, development of mixed cropping systems etc. In long-term field contaminated soil, enhancement of bioavailability appears to be the key of successful biodegradation. Phytoremediation is still a new field which holds great potential and in order to develop this potential requires a multidisciplinary approach, spanning field as diverse as plant biology, agricultural engineering, agronomy, soil science, microbiology and genetic engineering. Finally, the applicability of these bio-approaches for rehabilitation of contaminated soils needs to be fully demonstrated in the fields for wider acceptability.

\section{REFERENCES}

[1] P. K. Chhonkar, S. Bhadraray and T. J. Purakayastha, "Phytoremediation of Heavy Metal Contaminated Soils," Monograph, Division of Soil Science and Agricultural Chemistry, Indian Agricultural Research Institute, New Delhi, 2007.

[2] Y. B. Sun, Q. X. Zhou and C. Y. Diao, "Effects of Cadmium and Arsenic on Growth and Metal Accumulation of Cd-Hyperaccumulator Solanum nigrum L.," Bioresource Technology, Vol. 99, No. 5, 2008, pp. 1103-1110.

[3] X. Zhang, H. Xia, Z. Li, P. Zhuang and B. Gao, "Potential of Four Forage Grasses in Remediation of Cd and $\mathrm{Zn}$ Contaminated Soils," Bioresource Technology, Vol. 101, No. 6, 2010, pp. 2063-2066.

[4] C. Garbisu and I. Alkorta, "Phytoextraction: A Costeffective Plant-Based Technology for the Removal of Metals from the Environment," Bioresource Technology, Vol. 77, No. 3, 2001, pp. 229-236.

[5] S. P. McGrath, F. J. Zhao and E. Lombi, "Plant and Rhizosphere Processes Involved in Phytoremediation of Metal Contaminated Soils," Plant and Soil, Vol. 232, No. 1, 2001, pp. 207-214.

[6] M. C. Steele, and J. Pichtel, "Ex-situ Remediation of Metal Contaminated Superfund Soil using Selective Extractants," Journal of Environmental Engineering, Vol. 124, No. 7, 1998, pp. 639-645.

[7] R. B. King, G. M. Long, and J. K. Sheldon, "Practical Environmental Bioremediation the Field Guide," Boca Raton, Lewis Publishers, 1998.

[8] National Research Council, "In Situ Bioremediation When Does it Work?" National Academy Press, Washington D.C., 1993.

[9] W. W. Wenzel, "Rhizosphere Processes and Management in Plant-Assisted Bioremediation (Phytoremediation) of Soils," Plant and Soil, Vol. 321, No. 1, 2009, pp. 385408.

[10] T. A. Anderson, E. A. Guthrie and B. T. Walton, "Bioremediation in the Rhizosphere. Plant Roots and Associated Microbes Clean Contaminated Soil," Environmental Science and Technology, Vol. 27, No.13, 1993, pp. 26302636.

[11] J. G. Cruickshank, "Soil and Environment: Northern Ire- land," Department of Agriculture for Northern Ireland and Queen's University Belfast, Belfast, 1997, p.192.

[12] R. L. Chaney, "Zinc Phytotoxicity," In: A. D. Robson, Ed., Zinc in Soils and Plants, Kluwer Academic Publishers, Dordrecht, The Netherlands, 1988, pp. 135-150.

[13] F. M. Fahnestock, G. B. Wickramanayake, K. J. Kratzke and W. R. Major, "Biopile Design, Operation, and Maintenance Handbook for Treating Hydrocarbon Contaminated Soil," Battelle Press, Columbus, 1998.

[14] R. Idris, R. Trifonova, M. Puschenreiter, W. W. Wenzel and A. Sessitsch, "Bacterial Communities Associated with Flowering Plants of Ni Hyperaccumulator Thlaspi Goesingense," Applied Environmental Microbiology, Vol. 70, No. 5, 2004, pp. 2667-2677.

[15] C. Lodewyckx, M. Mergeay, J. Vangronsveld, H. Clijsters and L. D. Vander, "Isolation, Characterization, and Identification of Bacteria Associated with the Zinc Hyperaccumulator Thlaspi Caerulescens Subsripton. Calaminaria," International Journal of Phytoremediation, Vol. 4, No. 2, 2002, pp. 101-115.

[16] M. M. Lasat, A. J. M. Baker and L. V. Kochian, "Physiological Characterisation of Root $\mathrm{Zn}^{2+}$ Absorption and Translocation to Shoots in $\mathrm{Zn}$ Hyperaccumulator and Nonaccumulator Species of Thlaspi," Plant Physiology, Vol. 112, No. 4, 1996, pp. 1715-1722.

[17] R. A. Abou-Shanab, J. S. Angle, T. A. Delorme, R. L. Chaney, P. Berkum, H. Moawad, K. Ghanem and H. A. Ghozlan, "Rhizobacterial Effects on Nickel Extraction from Soil and Uptake by Alyssum Murale," New Phytologist, Vol. 158, No. 1, 2003, pp. 219-224.

[18] B. R. Glick, "Phytoremediation: Synergistic use of Plants and Bacteria to Clean up the Environment," Biotechnology Advances, Vol. 21, No. 5, 2003, pp. 383-393.

[19] S. N. Whiting, M. P. De Souza and N. Terry, "Rhizosphere Bacteria Mobilize Zn for Hyperaccumulation by Thlaspi caerulescens," Environmental Science \& Technology, Vol. 35, No. 15, 2001, pp. 3144-3150.

[20] M. E. Losi, C. Amrhein and W. T. J. Frankenberger, "Bioremediation of Chromate-contaminated Groundwater by Reduction and Precipitation in Surface Soils," Journal of Environmental Quality, Vol. 23, 1994(a), pp. 11411150 .

[21] M. E. Losi, C. Amrhein and W. T. J. Frankenberger, "Factors Affecting Chemical and Biological Reduction of Hexavalent Chromium in Soil," Environmental Toxicology and Chemistry, Vol. 13, No. 11, 1994(b), pp. 1727 1735.

[22] S. E. Smith and D. J. Read, "Mycorrhizal Symbiosis," 2nd Edition, Academic Press, London, 1997.

[23] Y. T. Wang and H. Shen, "Bacterial Reduction of Hexavalent Chromium," Journal of Industrial Microbiology, Vol. 14, 1995, p. 159.

[24] H. Ohtake and S. Silver, "Bacterial Detoxification of Toxic Chromate," In: G. R. Chaudry, Ed., Biological Degradation and Bioremediation of Toxic Chemicals, Dioscorides Press, 1994, pp. 403-415. 
[25] L. Bopp and H. L. Ehrlich, "Chromate Resistance and Reduction in Pseudomonas fluorescens Strain LB300," Achieve of Microbiology, Vol. 150, 1998, p. 426.

[26] C. Cervantes and H. Ohtake, "Plasmid-Determined Resistance to Chromate in Pseudomonas aeruginosa," FEMS Microbiology Letters, Vol. 56, No. 2, 1988, pp. 173.

[27] P. B. Salunkhe, P. K. Dhakephalkar and K. M. Paknikar, "Bioremediation of Hexavalent $\mathrm{Cr}$ in Soil Microcosms," Biotechnology Letters, Vol. 20, No. 8, 1998, pp. 749-751.

[28] J. L. Bader, G. Gonzalez and P. C. Goodell, "Chromium-Resistant Bacterial Populations from a Site Heavily Contaminated with Hexavalent Cr.," Water, Air and Soil Pollution, Vol. 109, No. 1-4, 1999, pp. 263-276.

[29] A. Mengoni, R. Barzanti, C. Gonnelli, R. Gabbrielli and M. Bazzicalupo, "Characterization of Nickel-Resistant Bacteria Isolated from Serpentine Soil," Environmental Microbiology, Vol. 3, 2001, pp. 691-708.

[30] T. J. Beveridge and R. Doyle, "Metal Ions and Bacteria," Wiley, New York, 1989.

[31] N. Terry, C. Karlson, T. K. Raab and A. M. Zayed, "Rates of Selenium Volatilization among Crop Species," Journal of Environmental Quality, Vol. 21, No. 3, 1992, pp. 341-344.

[32] M. T. Brown and D. A. Wilkins, "Zinc Tolerance of Mycorrhizal Betula," New Phytologist, Vol. 99, 1985, pp. 101-106.

[33] J. L. Wasserman, L. Mineo, S. K. Majumdar and C. Vantyne, "Detection of Heavy Metals in Oak My-Corrhizae of Northeastern Pennsylvania Forests, Using X-Ray Microanalysis," Canadian Journal of Botany, Vol. 65, No. 12, 1987, pp. 2622-2627.

[34] G. Rufyikiri, L. Huysmans, J. Wannijn, M. van Hees, C. Leyval and I. Jakobsen, "Arbuscular Mycorrhizal Fungi can Decrease the Uptake of Uranium by Subterranean Clover Grown at High Levels of Uranium in Soil," Environmental Pollution, Vol. 130, 2004(b), No. 3, pp. 427436.

[35] G. Rufyikiri, Y. Thiry and S. Declerck, "Contribution of Hyphae and Roots to Uranium Uptake and Translocation by Arbuscular Mycorrhizal Carrot Roots under Root-Organ Culture Conditions," New Phytology, Vol. 158, No. 2, 2003, pp. 391-399.

[36] G. Rufyikiri, S. Declerck and Y. Thiry, "Comparison of ${ }^{233} \mathrm{U}$ and ${ }^{33} \mathrm{P}$ Uptake and Translocation by the Arbuscular Mycorrhizal Fungus Glomus Intraradices in Root Organ Culture Conditions," Mycorrhiza, Vol. 14, 2004(a), pp. 203-207.

[37] H. Shahandeh and L. R. Hossner, "Enhancement of Uranium Phytoaccumulation from Contaminated Soils," Soil Science, Vol. 167, No. 4, 2002, pp. 269-280.

[38] S. D. Ebbs, D. J. Brady and L. V. Kochian, "Role of Uranium Speciation in the Uptake and Translocation of Uranium by Plants," Journal of Experimental Botany, Vol. 49, No. 324, 1998, pp. 1183-1190.

[39] J. L. J. Jerden, A. K. Sinha and L. Zelazny, "Natural Immobilization of Uranium by Phosphate Mineralization in an Oxidizing Saprolite-Soil Profile: Chemical Weathering of the Coles Hill Uranium deposit, Virginia," Chemical Geology, Vol. 199, No. 1, 2003, pp. 129-157.

[40] A. Heggo, J. S. Angle and R. L. Chaney, "Effects of Vesiculararbuscular Mycorrhizal Fungi on Heavy Metal Uptake by Soybeans," Soil Biology and Biochemistry, Vol. 22, 1990, No. 6, pp. 865-869.

[41] B. A. D. Hetrick, G. W. T. Wilson and D. A. H. Figge, "The Influence of Mycorrhizal Symbiosis and Fertilizer Amendments on Establishment of Vegetation in HeavyMetal Mine Spoil," Environmental Pollution, Vol. 86, No. 2, 1994, pp. 171-179.

[42] G. Diaz and M. Honrubia, "A Mycorrhizal Survey of Plants Growing on Mine Wastes in Southeast Spain," Arid Soil Research and Rehabilitation, Vol. 8, 1994, pp. 59-68.

[43] T. E. Pawlowska, J. Blaszkowski and A. Ruhling, "The Mycorrhizal Status of Plants Colonizing a Calamine Spoil Mound in Southern Poland," Mycorrhiza, Vol. 6, No. 6, 1996, pp. 499-505.

[44] K. Sambandan, K. Kannan and N. Raman, "Distribution of Vesicular-arbuscular Mycorrhizal Fungi in Heavy Metal Polluted Soils of Tamil Nadu, India," Journal of Environmental Biology, Vol. 13, 1992, pp. 159-167.

[45] M. Kaldorf, A. J. Kuhn, W. H. Schroder, U. Hildebrandt and H. Bothe, "Selective Element Deposits in Maize Colonized by a Heavy Metal Tolerance Conferring Ar- buscular Mycorrhiza Fungus," Journal of Plant Physiol- ogy, Vol. 154, No.5-6, 1999, pp. 718-728.

[46] I. Weissenhorn, A. Glashoff, C. Leyval and J. Berthelin, "Differential Tolerance to $\mathrm{Cd}$ and $\mathrm{Zn}$ of Arbuscular Mycorrhizal (AM) Fungal Spores Isolated from Heavy Metal-Polluted and Unpolluted Soils," Plant and Soil, Vol. 167, No. 2, 1994, pp. 189-196.

[47] G. Diaz, C. Azcon-Aguilar and M. Honrubia, "Influence of Arbuscular Mycorrhizae on Heavy Metal ( $\mathrm{Zn}$ and $\mathrm{Pb}$ ) Uptake and Growth of Lygeum spartum and Anthyllis cytisoides," Plant and Soil, Vol. 180, No. 2, 1996, pp. 241249.

[48] I. Raskin and B. D. Ensley, "Phytoremediation of Toxic Metals: Using Plants to Clean-up the Environment," Wiley, New York, 2000.

[49] T. J. Purakayastha and P. K. Chhonkar, "Phytoremediation of Heavy Metal Contaminated Soils," In: Sherameti and A. Varma, Eds., Soil Heavy Metals, Soil Biology, Vol. 19, 2010, pp. 389-429.

[50] R. L. Chaney, M. Malik, Y. M. Li, S. L. Brown, J. S. Angle and A. J. M. Baker, "Phytoremediation of Soil Metals. Current Opinion," Biotechnology, Vol. 8, No. 3, 1997, pp. 279-284.

[51] P. B. A. Kumar, V. Dushenkov, H. Motto and I. Raskin "Phytoextraction: The Use of Plants to Remove Heavy Metals form Soil," Environmental Science and Technology, Vol. 29, No. 5, 1995, pp. 1232-1238.

[52] A. J. M. Baker, S. P. McGrath and C. M. D. Sidoli, "The Possibility of In-situ Heavy Metal Decontamination of Polluted Soil using Crops of Metal-accumulating Plants," 
Resource Conservation and Recycling, Vol. 11, No. 1-4, 1994, pp. 41-49.

[53] A. J. M. Baker and R. R. Brooks, "Terrestrial Higher Plants which Accumulate Metallic Elements: A Review of their Distribution, Ecology and Phytochemistry," Biorecovery, Vol. 1, 1989, pp. 81-126.

[54] D. E. Salt, R. D. Smith, and I. Raskin, "Phytoremediation. Annual Plant Physiology," Plant Molecular Biology, Vol. 49, 1998, pp. 643-668.

[55] W. W. Wenzel and F. Jockwer, "Accumulation of Heavy Metals Grown on Mineralized Soils of the Austrian Alps.," Environmental Pollution, Vol. 104, No. 1, 1999, pp. 145-155.

[56] A. K. Gupta and S. Sinha, "Phytoextraction Capacity of the Chenopodium album L. Grown on Soil Amended with Tannery Sludge," Bioresource Technology, Vol. 98, No. 2, 2007, pp. 442-446.

[57] R. S. Boyd and T. Javre, "Phytoenrichement of Soil Content by Sebertia acuminata in New Caledonia and the Concept of Elemental Alelopathy," South African Journal of Science, Vol. 97, No. 2, 2001, pp. 535-538.

[58] R. S. Boyd and S. N. Martens, "The Significance of Metal Hyperaccumulation for Biotic Interactions," Chemoecology, Vol. 8, No. 1, 1998, pp. 1-7.

[59] M. A. Davis, R. S. Boyd and J. H. Cane, "Host Switching does not Circumvent the Ni-Based Defense of the Ni Hyperaccumulator Streptanthus Polygaloides (Brassicaceae)," South African Journal Science, Vol. 97, No. 2, 2001, pp. 554-557.

[60] A. Bani, G. Echevarria, S. Sulçe, J. L. Morel, and A. Mullai, "In-situ Phytoextraction of Ni by a Native Population of Alyssum murale on an Ultramafic Site (Albania)," Plant and Soil, Vol. 293, 2007, No. 1, pp. 79-89.

[61] S. D. Ebbs, M. M. Lasat, D. J. Brady, J. Cornish, R. Gordon and L. V. Kochian, "Phytoextraction of Cadmium and Zinc from Contaminated Soil," Journal of Environmental Quality, Vol. 26, No. 5, 1997, pp. 1424-1430.

[62] M. M. Lasat, M. Fuhrman, S. D. Ebbs, J. E. Cornish and L. V. Kochian, "Phytoremediation of Radiocesium-contaminated Soil: Evaluation of Cesium-137 Bioaccumulation in the Shoots of Three Plant Species," Journal of Envirnmental Quality, Vol. 27, No. 1, 1998, pp. 165-169.

[63] W. J. Fitz, W. W. Wenzel, H. Zhang, J. Nurmi, K. Stipek, Z. Fischerova, P. Schweiger, G. Kollensperger, L. Q. Ma, and G. Stingeder, "Rhizosphere Characteristics of the Arsenic Hyperaccumulator Pteris vittata L. and Monitoring of Phytoremoval Efficiency," Environmental Science Technology, Vol. 37, No. 21, 2003, pp. 5008-5014.

[64] N. J. Lehto, W. Davison, H. Zhang and W. Tych, "Theoretical Comparison of how Soil Processes Affect Uptake of Metals by Diffusive Gradients in thin Films and Plants," Journal Environmental Quality, Vol. 35, No. 5, 2006, pp. 1903-1913.

[65] A. Kayser, K. Wenger, A. Keller, W. Attinger, H. R. Felix, and S. K. Gupta, "Enhancement of Phytoextraction of $\mathrm{Zn}, \mathrm{Cd}$ and $\mathrm{Cu}$ from Calcareous Soil: the use of NTA and Sulphur Amendments," Environmental Science Technol- ogy, Vol. 34, No. 9, 2000, pp. 1778-1783.

[66] A. S. Wang, J. S. Angle, R. L. Chaney, T. A. Delorme and R. D. Reeves, "Soil pH Effects on Uptake of Cd and Zn by Thlaspi Caerulescens," Plant and Soil, Vol. 281, No. 1, 2006, pp. 325-337.

[67] M. Puschenreiter, G. Stöger, E. Lombi, O. Horak, W. W. Wenzel, "Phytoextraction of Heavy Metal Contaminated Soils with Thlaspi Goesingense and Amaranthus Hybridus: Rhizosphere Manipulation Using EDTA and Ammonium Sulphate," Journal of Plant Nutrition Soil Science, Vol. 164, No. 6, 2001, pp. 615-621.

[68] P. Zaccheo, L. Crippa and D. M. V. Pasta, "Ammonium Nutrition as a Strategy for Cadmium Mobilisation in the Rhizosphere of Sunflower," Plant and Soil, Vol. 283, No. 1, 2006, pp. 43-56.

[69] B. Gove, J. J. Hutchinson, S. D. Young, J. Craigon and S. P. McGrath, "Uptake of Metals by Plants Sharing a Rhizosphere with the Hyperaccumulator Thlaspi Caerulescens," International Journal of Phytoremediation, Vol. 4, No. 4, 2002, pp. 267-281.

[70] C. Keller, D. Hammer, A. Kayser, W. Richner, M. Brodbeck and M. Sennhauser, "Root Development and Heavy Metal Phytoextraction Efficiency: Comparison of Different Plant Species in the Field," Plant and Soil, Vol. 249, No. 1, 2003, pp. 67-81.

[71] S. Roy, D. P. Khasa and C. W. Greer, "Combining Alders, Frankiae, and Mycorrhizae for the Revegetation and Remediation of Contaminated Ecosystems," Canadian Journal Botany, Vol. 85, No. 3, 2007, pp. 237-251.

[72] H. van Miegroet and D. W. Cole, "The Impact of Nitrification on Soil Acidification and Cation Leaching in Red Alder Ecosystems," Journal Environmental Quality, Vol. 13, 1984, pp. 86-590.

[73] P. Hinsinger, C. Plassard, C. Tang, and B. Jaillard, "Origins of Root-Induced $\mathrm{pH}$ Changes in the Rhizosphere and their Responses to Environmental Constraints: A Review," Plant and Soil, Vol. 248, No. 1, 2003, pp. 43-59.

[74] C. H. Wu, T. K. Wood, A. Mulchandani, and W. Chen, "Engineering of Plant-Microbe Symbiosis for Rhizoremediation of Heavy Metals," Applied Environmental Microbiology, Vol. 72, 2006, pp. 1129-1134.

[75] T. J. Purakayastha, V. Thulasi S. Bhadraray, P. K. Chhonkar, P. P. Adhikari and K. Suribabu, "Phytoextraction of Zinc, Copper, Nickel and Lead from a Contaminated Soil by Different Species of Brassica," International Journal Phytoremediation, Vol. 10, No. 1, 2008, pp. 63-74.

[76] J. W. Huang, W. Chen, W. R. Berti and S. D. Cunningham, "Phytoremediation of Lead Contaminated Soils: Role of Synthetic Chelates in Lead Phytoextraction," Environmental Science Technology, Vol. 31, No. 3, 1997, pp. 800-805.

[77] J. M. Blaylock, D. E. Salt, S. Dushenkov, O. Zakharova, C. Gussman, Y. Kapulnik, B. D. Ensley and I. Raskin, "Enhanced Accumulation of $\mathrm{Pb}$ in Indian Mustard by Soil-applied Chelating Agents," Environmental Science and Technology, Vol. 31, No. 3, 1997, pp. 860-865. 
[78] H. Zaier, T. Ghnaya, K. B. Rejeb, A. Lakhdar, S. Rejeb and F. Jemal, "Effects of EDTA on Phytoextraction of Heavy Metals ( $\mathrm{Zn}, \mathrm{Mn}$ and $\mathrm{Pb}$ ) from Sludge-Amended Soil with Brassica napus," Bioresource Technology, Vol. 101, No. 11, 2010, pp. 3978-3983.

[79] J. W. Huang and S. D. Cunningham, "Lead Phytoextraction: Species Variation in Lead Uptake and Translocation," New Phytology, Vol. 134, No. 1, 1996, pp. 75-84.

[80] C. Leyval, K. Turnau and K. Haselwandter, "Effect of Heavy Metal Pollution on Mycorrhizal Colonization and Function: Physiological, Ecological and Applied Aspects," Mycorrhiza, Vol. 7, No. 3, 1997, pp. 139-153.

[81] T. Ezawa, M. Saito and T. Yoshida, "Comparison of Phosphatase Localization in the Intraracial Hyphae of Arbuscular Mycorrhizal Fungi, Glomus spp. and Gigaspora spp.," Plant and Soil, Vol. 176, No. 1, 1995, pp. 57-63.

[82] J. R. Vestal and D. C. White, "Lipid Analysis and Microbialecology," BioScience, Vol. 39, No. 8, 1989, pp. 535541.

[83] C. G. Wilber, "Toxicology of Selenium: A Review," Clinical Toxicology, Vol. 17, No. 2, 1980, pp. 171-230.

[84] J. P. Buchet and R. Lauwerys, "Evaluation of Exposure to Inorganic Arsenic in Man. Analytical Techniques for Heavy Metals in Biological Fluids," Elsevier, Amsterdam, 1981.

[85] R. B. Meagher, C. L. Rugh, M. K. Kandasamy, G. Gragson and N. J. Wang, "Engineered Phytoremediation of Mercury Pollution in Soil and Water using Bacterial Genes," In: N. Terry and G. Bañuelos, Eds., Phytoremediation of Contaminated Soil and Water, Lewis, Boca Raton, 2000, pp. 201-220.

[86] R. E. Meagher and A. C. P. Heaton, "Strategies for the Engineered Phytoremediation of Toxic Element Pollution: Mercury and Arsenic," Journal of Industrial Microbiology and Microtechnology, Vol. 32, 2005, pp. 502-513.

[87] H. H. Liste and I. Prutz, "Plant Performance, Dioxygenaseexpressing Rhizosphere Bacteria, and Biodegradation of Weathered Hydrocarbons in Contaminated Soil," Chemosphere, Vol. 62, No. 9, 2006, pp. 1411-1420.

[88] H. H. Liste and D. Felgentreu, "Crop Growth, Culturable Bacteria, and Degradation of Petrol Hydrocarbons (PHCs) in a Longterm Contaminated Field Soil," Applied Soil Ecology, Vol. 31, No. 1-2, 2006, pp. 43-52.

[89] A. Y. Muratova, O. V. Turkovskaya, T. Hübner, and P. Kuschk, "Studies of the Efficacy of Alfalfa and Reed in the Phytoremediation of Hydrocarbon-Polluted Soil," Applied Biochemistry and Microbiology, Vol. 39, No. 6, 2003, pp. 599-605.

[90] P. E. Olson, A. Castro, M. Joern, N. M. DuTeau, E. A. H. Pilon-Smits and K. F. Reardon, "Comparison of Plant Families in a Greenhouse Phytoremediation Study on an Aged Polycyclic Aromatic Hydrocarbon-Contaminated Soil," Journal of Environmental Quality, Vol. 36, 2007, pp. 1461-1469.

[91] L. A. Phillips, C. W. Greer and J. J. Germida, "Culturebased and Culture-Independent Assessment of the Impact of Mixed and Single Plant Treatments on Rhizosphere Microbial Communities in Hydrocarbon Contaminated Flare-Pit Soil," Soil Biology and Biochemistry, Vol. 38, No. 9, 2006, pp. 2823-2833.

[92] G. Chiapusio, S. Pujol, M. L. Toussaint, P. M. Badot and P. Binet, "Phenanthrene Toxicity and Dissipation in the Rhizosphere of Grassland Plants (Lolium perenne L. and Trifolium pratense L.) in three Spiked Soils," Plant and Soil, Vol. 294, No. 1, 2007, pp. 103-112.

[93] R. Child, C. D. Miller, Y. Liang, R. C. Sims and A. J. Anderson, "Pyrene Mineralization by Mycobacterium sp. Strain KMS in a Barley Rhizosphere," Journal of Environmental Quality, Vol. 36, No. 5, 2007, pp. 1260-1265.

[94] R. I. Dams, G. I. Paton and K. Killham, "Rhizoremediation of Pentachlorphenol by Sphinobium chlorophenolicum ATCC 39723," Chemosphere Vol. 68, No. 5, 2007, pp. $864-870$.

[95] J. J. Gunderson, J. D. Knight and K. C. J. van Rees, “Impact of Ectomycorrhizal Colonization of Hybrid Poplar on the Remediation of Diesel-contaminated Soil," Journal of Environmental Quality, Vol. 36, No. 4, 2007, pp. 927-934.

[96] E. Kaimi, T. Mukaidani and M. Tamaki, "Effect of Rhizodegradation in Diesel-Contaminated Soil under Different Soil Condition," Plant Production and Science, Vol. 10, No. 1, 2007, pp. 105-111.

[97] J. Kim, S. H. Kang, K. A. Min, K. S. Cho and I. S. Lee, "Rhizosphere Microbial Activity during Phytoremediation of Diesel-Contaminated Soil," Journal Environmental Science and Health, Part A., Vol. 41, No. 11, 2006, pp. 2503-2516.

[98] Q. Lin, Z. Wang, S. Ma and Y. Chen, "Evaluation of Dissipation Mechanisms by Lolium perenne L, and Raphanus sativus for Pentachlorophenol (PCP) in Copper Co-contaminated Soil," Science of Total Environment, Vol. 368, No. 2-3, 2006, pp. 814-822.

[99] Q. Wang, X. Fang, B. Bai, X. Liang, P. J. Shuler and W. A. Goddard, "Engineering Bacteria for Production of Rhamnolipid as an Agent for Enhanced Oil Recovery," Biotechnology and Bioengineering, Vol. 8, No. 4, 2007, pp. 842-853.

[100] D. C. Yee, J. A. Maynard and T. K. Wood, "Rhizoremediation of Trichloroethylene by a Recombinant, Rootcolonizing Pseudomonas fluorescens Strain Expressing Toluene Ortho-monooxygenese Constitutively," Applied Environmental Microbiology, Vol. 64, No. 1, 1998, pp. 112-118.

[101] R. M. Atlas, "Bioremediation of Petroleum Pollutants," International Biodeterioration and Biodegradation, Vol. 35, No. 1-3, 1995, pp. 317-327.

[102] J. R. Bragg, R. C. Prince, E. J. Harner and R. M. Atlas, "Effectiveness of Bioremediation for the Exxon Valdes Oil Spill," Nature, Vol. 368, No. 6740, pp. 413-418.

[103] J. D. van Hamme, A. Singh and O. P. Ward, "Recent Advances in Petroleum Microbiology," Microbiology and Molecular Biology Review, Vol. 67, No. 4, 2003, pp. 503549. 
[104] A. L. Wright, R. W. Weaver and J. W. Webb, “Oil Bioremediation in Salt Marsh Mesocosms as Influence by $\mathrm{N}$ and P Fertilization, Flooding and Season," Water Air and Soil Pollution, Vol. 95, No. 1-4, 1997, pp. 179-191.

[105] D. B. Read, A. G. Bengough, P. J. Gregory, J. W. Crawford, D. Robinson and C. M. Scrimgeour, "Plant Roots Release Phospholipids Surfactants that Modify the Physical and Chemical Properties of Soil," New Phytologist, Vol. 157, No. 2, 2003, pp. 315-326.

[106] P. Henner, M. Schiavon, J. L. Morel and E. Lichtfouse, "Polycyclic Aromatic Hydrocarbon (PAH) Occurrence and Remediation Methods," Analusis, Vol. 25, 1997, pp. M56-M59.

[107] P. J. Harvey, B. F. Campanella, P. M. L. Castro, H. Harms, E. Lichtfouse, A. R. Schaffner, S. Smrcek and D. Werck-Reichhart, "Phytoremediation of Polyaromatic Hydrocarbons, Anilines and Phenols," Environmental Science and Pollution Research, Vol. 9, No. 9, 2002, pp. 29-47.

[108] J. D. Cotter-Howells, P. E. Champness and J. M. Charnock, "Mineralogy of Lead Phosphorus Grains in the
Roots of Agrostis capillaris L by ATEM and EXAFS," Min. Mag. (Lond), Vol. 63, No. 6, 1999, pp. 777-789.

[109] J. D. Cotter-Howells, P. E. Champness, J. M. Charnock and R. A. D. Pattrick, "Identification of Pyromorphite in Mine-Waste Contaminated Soils by ATEM and EXAFS," European Journal of Soil Science, Vol. 45, No. 4, 1994, pp. 393-402.

[110] J. D. Cotter-Howells and S. Caporn, "Remediation of Contaminated Land by Formation of Heavy Metal Phosphates," Applied Geochemistry, Vol. 11, No. 2, 1996, pp. 335-342.

[111] W. Lee, T. K. Wood and W. Chen, "Engineering TCEdegrading Rhizobacteria for Heavy Metal Accumulation and Enhanced TCE Degradation," Biotechnology and Bioengineering, Vol. 95, No. 3, 2006, pp. 399-403.

[112] P. Wang, T. Mori, K. Komori, M. Sasatsu, K. Toda and H. Ohtake, "Isolation and Characterization of an Enterobacter-Cloacae Strain that Reduces Hexavalent Chromium under Anaerobic Conditions," Applied Environmental Microbiology, Vol. 55, No. 7, 1989, pp. 1665-1669. 